\title{
Uterine cervix squamous cell carcinoma metastatic to the Ampulla of Vater: a case report with review of the literature
}

\author{
Dalma Udovičić-Gagula1* , Faruk Skenderi' ${ }^{1}$ Srđan Gornjaković², Nermina Ibišević1, \\ Adisa Chikha1, Semir Vranić1, Aleksandra Đuran ${ }^{1}$
}

'Department of Clinical Pathology and Cytology, University of Sarajevo Clinical Center, Bolnička 25, 71000 Sarajevo, Bosnia and Herzegovina. 'Department of Gastroenterohepatology, University of Sarajevo Clinical Center, Bolnička 25, 71000 Sarajevo, Bosnia and Herzegovina

\begin{abstract}
Metastases to gastrointestinal tract are uncommon. In particular, metastases to the ampulla of Vater are very rare and may represent a significant diagnostic challenge. Metastases from the uterine cervix to the ampulla of Vater are exceedingly rare and only one case has been described in the available literature. We describe here a second case of metastatic squamous cell carcinoma of the cervix to the ampulla of Vater in a 45-year-old woman. Poorly differentiated squamous cell carcinoma presented as an isolated metastasis to the ampulla of Vater, two years after the initial diagnosis. While the squamous cell carcinoma could occur as primary ampullary carcinoma, albeit very rare, it is necessary to exclude the possibility of metastatic cancer.
\end{abstract}

Keywords: Ampulla of Vater, Neoplasms, Metastasis, Squamous Cell Carcinoma, Cervix, Uterus

\section{INTRODUCTION}

Primary tumors of the ampulla of Vater are rare and are usually adenocarcinomas $(1,2)$. Metastases to the gastrointestinal tract (GI) tract are uncommon, while metastases to the ampulla of Vater are extremely rare and therefore may pose a significant diagnostic pitfall. Not many cases of metastasis to

\footnotetext{
*Corresponding author: Dalma Udovičić-Gagula Department of Clinical Pathology and Cytology University of Sarajevo Clinical Center; Bolnička 25 BA-71000 Sarajevo; Bosnia and Herzegovina Phone: +387 61 505315; Fax: +387 33297826 E-mail address: dalma_u@yahoo.com
}

Submitted 28 July 2013 / Accepted 20 August 2013 the ampulla of Vater are described, most of them being metastasis of primary melanoma of the skin (3-7), renal cell carcinomas (8-10) and a few cases of squamous cell carcinoma (SCC) from different primary sites (11-13). SCC of the uterine cervix is likely to early metastasize into the adjacent lymph nodes, but hematogenous dissemination is the least common metastatic pathway of this carcinoma (14). Only one case of uterine cervix SCC metastasis to the ampulla of Vater has been described up to now (13).

Here, we report a second case of metastasis of squamous cell carcinoma (SCC) of the uterine cervix to the ampulla of Vater. 


\section{CASE REPORT}

\section{Clinical history}

A 45-year-old woman presented with one month history of abdominal pain, jaundice and dark-colored urine. Physical examination revealed skin and conjunctival jaundice. Two years earlier she had been diagnosed with the primary squamous cell carcinoma of the uterine cervix (grade 3, FIGO stage IIIB). Due to the advanced stage, it was treated with a concomitant radiochemotherapy.

Laboratory tests on admission revealed elevated levels of total bilirubin $114.8 \mu \mathrm{mol} / \mathrm{L}$, aspartate amino transferase (AST) $158 \mathrm{IU} / \mathrm{L}$ and alanin amino transferase (ALT) $210 \mathrm{IU} / \mathrm{L}$. Other laboratory findings were within or close to normal: white blood cell (WBC) count $7 \times 10^{9} / \mathrm{L}$, red blood cell (RBC) count $4.16 \times 10^{12} / \mathrm{L}$, platelet (Plt) count $459 \times 10^{9} / \mathrm{L}$, hemoglobin $(\mathrm{Hb}) 121 \mathrm{~g} / \mathrm{L}$, glucose $6.4 \mathrm{mmol} / \mathrm{L}$, urea 4.4 $\mathrm{mmol} / \mathrm{L}$ and creatinine $74 \mu \mathrm{mol} / \mathrm{L}$.

Abdominal ultrasound revealed a folded gall bladder and dilatation of intra- and extrahepatic bile ducts, while common bile duct and pancreatic duct were not clearly exposed due to the presence of air within the intestinal lumen. Abdominal and pelvic CT scan revealed enlarged retroperitoneal lymph nodes with possible external compression of excretory bile ducts causing obstruction and jaundice.

Endoscopic retrograde cholangiopancreatography was performed and during the endoscopy a polypoid tumor with ulcerated surface was found at the ampulla of Vater site (Figure 1). In the same procedure, papillectomy was performed and stent was placed. The specimen was submitted for histopathologic evaluation.

\section{Histopathology and immunohistochemistry}

Grossly, the specimen measured 20x15x4 mm, oval shaped, grayish tissue with smooth surface and visible superficial ulceration.

Histological examination revealed a highly cellular tumor, composed of heterogeneous population of the neoplastic cells with oval to round nuclei and cells with spindle appearance, diffusely infiltrating mucosa and submucosa of the ampullar region. Tumor cells were arranged as solid islands with focal fascicular pattern. There was a sporadic mitotic activity and focal necrosis (Figure 1). Tumor surface was ulcerated and replaced by granulation tissue. The morphology indicated poorly differentiated malignant neoplasm including primary tumors (e.g. neuroendocrine carcinoma, gastrointestinal stromal tumor (GIST) with spindled pattern and poorly differentiated carcinoma). Because of her history of primary cervical cancer the metastasis was also considered in differential diagnosis.

Immunochistochemical (IHC) analysis revealed that the tumor cells were negative for Chromogranin-A, CD56, c-Kit (CD117), CD34, ruling out the neuroendocrine carcinoma and GIST (Figure 2). Cytokeratins (CK)7 and 20 were also negative which excluded primary, poorly differentiated ampullary carcinoma (Figure 2). The tumor cells were strongly positive for CK5/6 and p16 (Figure 2), which favored metastatic poorly differentiated squamous cell carcinoma originating from uterine cervix.

The patient was administered new cycles of cisplatinbased chemotherapy.
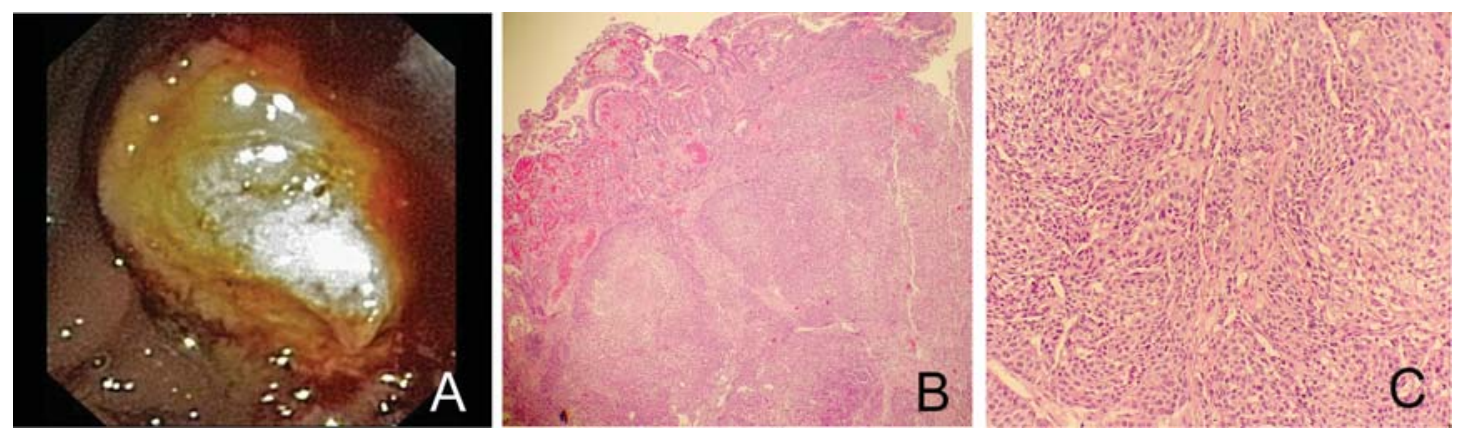

RGURE 1. Polypoid tumor with ulcerated surface at the Ampulla of Vater (A). Histopathologic examination revealed a highly cellular tumor nests and islands composed of heterogenous population of malignant cells diffusely infiltrating mucosa and submucosa of the ampullar region $(B, C)$. 

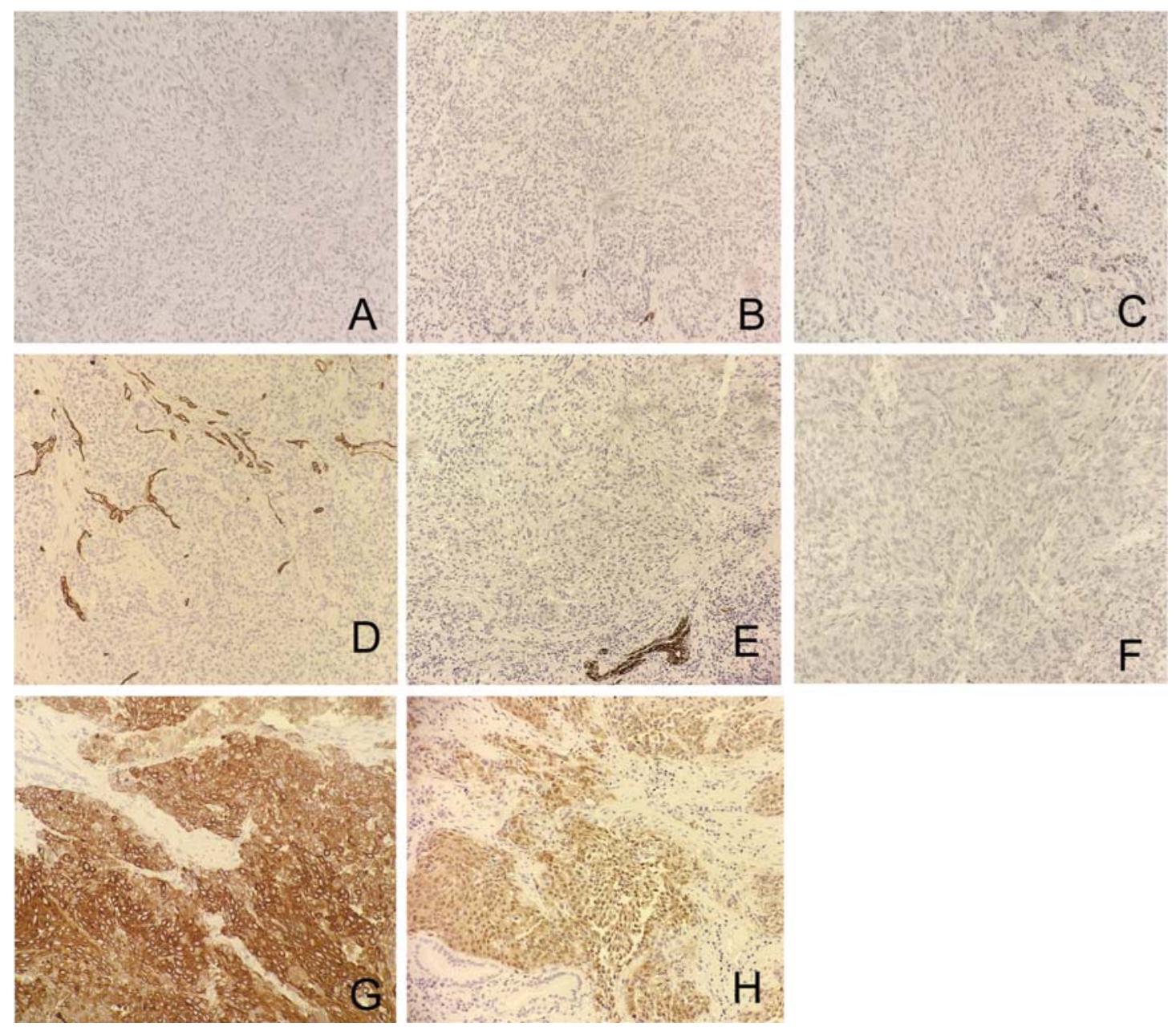

RGURE2 Immunohistochemical profile of the tumor. Chromogranin-A, CD56, CD117, CD34, CK7 and CK20 were negative (A, $B, C, D, E$ and $F$, respectively). CK5/6 and p16 were strongly positive ( $G$ and $H$, respectively). CK: cytokeratin.

\section{DISCUSSION}

Primary carcinomas of the ampulla of Vater comprise about $0.5 \%$ of all GI tumors and most of them are adenocarcinomas (90\%) (15). Metastases to the ampulla of Vater are unusual and small number of cases are reported in the available literature. We report here a second case of metastatic squamous cell carcinoma from the uterine cervix that presented as an isolated metastasis to the ampulla of Vater, two years after the initial diagnosis. Our extended literature search (PubMed, Google Scholar, Scopus, Web of Science) revealed only three metastatic squamous cell carcinomas to the ampulla of Vater, including single cases originating from larynx, esophagus and uterine cervix (11-13).
Majority of these patients present with obstructive symptoms of the biliary tract. Our patient also presented with jaundice and abdominal pain; her laboratory findings showed elevated bilirubin and liver enzymes in the serum and dark-colored urine, which was consistent with cholestasis and presence of obstructive pathology. Although there was a known history of uterine cervix carcinoma, the most common cause of obstructive jaundice, i.e. trapped gallstones, had to be excluded.

Recent studies suggest that one third of patients with ampullary carcinoma could have synchronous malignancy (16). Endoscopic findings and morphologic appearance of the tumor were inconclusive and therefore we performed an extended IHC panel to 
render the correct diagnosis. Negativity for CK7, CK20, Chromogranin-A, CD56, CD34, and c-Kit along with diffuse and strong positivity for CK5/6 and p16 (INK4a) strongly favored metastatic squamous cell carcinoma originating from uterine cervix.

We conclude that metastatic tumors to the GI sites such as the ampulla of Vater are exceptionally rare and may pose a substantial diagnostic challenge. In such cases, a thorough histopathologic examination and an extended immunohistochemical panel, along with clinical history, are of utmost importance for the appropriate diagnosis and optimal clinical management of the patients.

\section{CONFLICT OF INTEREST}

The authors declare no conflict of interest.

\section{REFERENCES}

1. Heinrich S, Clavien PA. Ampullary cancer. Curr Opin Gastroenterol. 2010 May;26(3):280-5.

2. Ishibashi $Y$, Ito $Y$, Omori K, Wakabayashi K. Signet ring cell carcinoma of the ampulla of vater. A case report. JOP. 2009;10(6):690-3.

3. Uiterwaal MT, Mooi WJ, Van Weyenberg SJ. Metastatic melanoma of the ampulla of Vater. Dig Liver Dis. 2011 Apr;43(4):e8.

4. Bendic A, Glavina Durdov M, Stipic R, Karaman I. Melanoma in the ampulla of Vater. Hepatobiliary Pancreat Dis Int. 2013 Feb;12(1):106-8.

5. Marks JA, Rao AS, Loren D, Witkiewicz A, Mastrangelo MJ, Berger AC. Malignant melanoma presenting as obstructive jaundice secondary to metastasis to the Ampulla of Vater. JOP. 2010;11(2):173-5.
6. van Bokhoven MM, Aarntzen EH, Tan AC. Metastatic melanoma of the common bile duct and ampulla of Vater. Gastrointest Endosc. 2006 May;63(6):873-4.

7. Nakayama H, Miyazaki S, Kikuchi H, Saito N, Shimada H, Sakai S, et al. Malignant vaginal melanoma with metastases to the papilla of Vater in a dialysis patient: a case report. Intern Med. 2011;50(4):345-9.

8. Venu RP, Rolny P, Geenen JE, Hogan WJ, Komorowski RA, Ferstenberg R. Ampullary tumor caused by metastatic renal cell carcinoma. Dig Dis Sci. 1991 Mar;36(3):376-8.

9. Franssen B, Chan C, Ramirez-Del Val A, Llamas F, Lopez-Tello A. [Renal cell carcinoma metastatic to the duodenum and Vater ampulla: Report of two cases]. Rev Gastroenterol Mex. 2011 Oct-Dec;76(4):375-9.

10. Leslie KA, Tsao JI, Rossi RL, Braasch JW. Metastatic renal cell carcinoma to ampulla of Vater: an unusual lesion amenable to surgical resection. Surgery. 1996 Mar;119(3):349-51.

11. Buyukcelik A, Ensari A, Sarioglu M, Isikdogan A, Icli F. Squamous cell carcinoma of the larynx metastasized to the ampulla of Vater. Report of a case. Tumori. 2003 Mar-Apr;89(2):199-201.

12. Sreenarasimhaiah J, Hoang MP. Esophageal squamous cell carcinoma with metastasis to the ampulla. Gastrointest Endosc. 2005 Aug;62(2):3101 ; discussion 1.

13. Lee TH, Park SH, Lee CK, Lee SH, Chung IK, Kim SJ, et al. Ampulla of Vater metastasis from recurrent uterine cervix carcinoma presenting as groove pancreatitis. Gastrointest Endosc. 2011 Feb;73(2):362-3.

14. Witkiewicz AK, Wright TC, Ferenczy A, Ronnett BM, Kurman RJ. Carcinoma and Other Tumors of the Cervix. In: Kurman RJ, Ellenson LH, Ronnett BM, editors. Blaustein's Pathology of the Female Genital Tract. 6th ed. Heidelberg: Springer; 2011. pp. 253-303.

15. Albores-Saavedra J, Schwartz AM, Batich K, Henson DE. Cancers of the ampulla of vater: demographics, morphology, and survival based on 5,625 cases from the SEER program. J Surg Oncol. 2009 Dec 1;100(7):598-605.

16. Pathak GS, Deshmukh SD, Yavalkar PA, Ashturkar AV. Coexistent ampullary squamous cell carcinoma with adenocarcinoma of the pancreatic duct. Saudi J Gastroenterol. 2011 Nov-Dec;17(6):411-3. 